\title{
British Workers and Ottoman Modernity in Nineteenth-Century Istanbul ${ }^{1}$
}

\author{
Akın Sefer (D) \\ Koç University, History, Istanbul, 34450, Turkey \\ Corresponding author: E-mail: aksefer@ku.edu.tr
}

(Received 22 November 2019; revised 9 July 2020; accepted 19 July 2020)

\begin{abstract}
In the mid-nineteenth century, when the Ottoman state launched an industrialization campaign within the context of increasing contacts between the Ottoman and British governments, hundreds of British industrial workers migrated to Istanbul to work in Ottoman military factories, along with technology transfer from Britain. This article narrates the history of these workers and of the community they established in Istanbul in a period spanning four decades, from the beginning of the mechanization efforts in the 1830s until the economic crisis in the mid-1870s. Drawing on archival evidence from Ottoman and British sources, it analyzes the larger context of British workers' migration from Britain, their relations with the Ottoman state officials and local workers, and their experiences and struggles in the workplace and the city. Although both British and Ottoman historians have largely ignored their experiences due to their marginal numbers and distinct statuses, these workers actively took part in the Ottoman industrialization process, in the development of capitalist class relations, and in the social, cultural, and spatial transformation of the capital city in the Ottoman age of reforms. By means of this analysis, the article aims to highlight the significance of immigrant workers as actors of the history of large-scale transformations in the late Ottoman Empire as well as underlining the role of trans-imperial labor migration in the history of modernity.
\end{abstract}

\section{Introduction}

In 1868, James Herdman, aka Haddad Bey, wrote a long letter to the Ottoman Minister of Marine, asking for a pension to leave his post and go back home. Hired as a blacksmith (hence "Haddad"), he had served in the Imperial Arsenal for twenty-nine years "without leave," twenty-six years of which he acted as the Chief Engineer of the Arsenal, in the rank of colonel (miralay). "But time changes everything and has changed my circumstances also," he said in the letter, referring to his replacement with another Englishman and his recent relegation to the post of second engineer, since the Ottoman administration found his skills outmoded and incompatible with the requirements of the new era of ironclads. Regarding his

(C) International Labor and Working-Class History, Inc., 2021. This is an Open Access article, distributed under the terms of the Creative Commons Attribution licence (http://creativecommons.org/licenses/by/4.0/), which permits unrestricted re-use, distribution, and reproduction in any medium, provided the original work is properly cited. 
accomplishments during his long tenure, he was aware that these "may be considered as nothing and not worthy of being taken notice of" at the present age of stunning developments in shipbuilding. "Be that as it may, these matters are everything to me" he continued, underlining his personal dedication to the transformation of the Arsenal and taking pride in the fact that it took place under his own supervision. ${ }^{2}$

In the nineteenth century, the Ottoman Empire underwent dramatic changes that were largely catalyzed by the global processes of industrial and political transformations in this period. ${ }^{3}$ On the one hand, reformist statesmen launched an ambitious political and economic program, known as the Tanzimat (reorganization), in an effort to keep pace with these processes, as rapid top-down reforms were perceived as inevitable for the survival of the state in the face of massive military defeats that threatened its legitimacy. ${ }^{4}$ On the other hand, the Ottoman integration to global capitalist networks intensified especially by means of closer political and economic relations with Britain and other European countries. ${ }^{5}$ As these processes defined Ottoman modernization in the nineteenth century, people living in the Ottoman Empire, particularly those in Istanbul and other port cities where the application of reform policies was more efficient and connections with Europe were stronger, experienced them in distinct and diverse ways.

Herdman's paradoxical experience of and feeling toward these changes, as reflected in his letter, was in no way unique to him, but rather points to a crucial, but often neglected, dimension of Ottoman modernity. ${ }^{6}$ In parallel to increasing political and economic connections with Europe, tens of thousands of people from European countries migrated into the Ottoman Empire during this period. Research on these immigrants has so far largely concentrated on merchants or middle classes in the port cities, which became the bedrock of Ottoman integration to capitalist networks. ${ }^{7}$ Only more recently, scholars have started to unearth the experiences of lower class European migrants in the modern era, expanding the frontiers of earlier historiography. ${ }^{8}$

Following the footsteps of these recent studies, this article focuses on British industrial workers employed in the state factories in mid-nineteenth century Istanbul, who were located at the heart of social, economic, and cultural changes in this period. These workers were actively involved in some of these transformation processes, by means of their role in the mechanization of Ottoman industry, the formation of capitalist class relations, and urban-cultural transformation in the capital city, highlighting the significance of trans-imperial/transnational labor migration in the making of these processes. ${ }^{9}$ Nevertheless, we know very little about their experiences, apparently due to their marginal numbers and their distinct socio-economic positions. Indeed, studies on the emigration of British industrial workers in the nineteenth century have mostly focused on large-scale migration flows, mostly to the United States, leaving untold the experiences of "minorities who went to the Continent," or in our case, the Ottoman Empire. ${ }^{10}$ Ottoman/Middle Eastern historians who mentioned British industrial workers, on the other hand, often confined their references to the latter's distinct mechanical skills, their statuses as "experts" or "engineers," and their high wages. ${ }^{11}$

Official reports sent from the British diplomatic agents in Istanbul confirmed that labor migration from Britain in the nineteenth century remained marginal and mostly limited to state-run military factories. According to a report written in December 1869, British "artizans" in Istanbul were largely concentrated in the 
Imperial Arsenal (Tersane-i Amire) of the Ottoman navy, which employed around two hundred shipbuilders and mechanics from Britain, and in the Imperial Armory (Tophane-i Amire), where around twenty-five British mechanics worked. They had a tiny community even within the foreign population of the city in this period. In fact, the report argued, the fact that the French, Germans, and Italians had larger communities facilitated the migration of their own natives, giving them an "advantage" over the British. ${ }^{12}$

In his dispatch sent around the same period, the British Consul-General, arguing that "Turkey is not a field for British immigration," referred to the low standards, high expenses, and the "oppressive and arbitrary" mode of government to explain why it was so. ${ }^{13}$ Still, a British working-class colony came into being in a village on the Golden Horn, the epicenter of Ottoman industry in this period. Members of this colony showed that, despite their small numbers, they could still make their voices heard by both Ottoman and British authorities in order to solve their problems. They managed to do this by effectively making use of their critical role in the production process, their ability to build up and sustain a distinct community, and their pragmatic use of British citizenship, especially against the Ottoman government. It was, however, this effectiveness that impeded the growth of the British immigrant community as well as its survival into the last quarter of the nineteenth century.

I will analyze the stories of these workers in four parts. The first part gives an overview of British labor migration in the mid-nineteenth century, demonstrating that the dynamics of labor migration from Britain were shaped by a continuously changing imperial and inter-imperial context in this period as well as the agency of these workers. The second part narrates the formation of a British working-class colony in the 1860s and 1870s in Istanbul, and how this community became an important actor of cultural and spatial transformation in the city in this period. I will then analyze the relations between the Ottoman state, British diplomatic agents, and the workers to demonstrate how these relations evolved in a way that increasingly polarized the state and British workers over labor problems. In the final part, I narrate how these problems, within the context of economic crisis, pushed the Ottoman government to dismiss these workers, which ended up with the dissolution of a oncepromising working-class community in Istanbul.

\section{British Labor Migration in the Nineteenth Century}

Following a naval alliance against the rebel governor of Egypt Mehmed Ali Pasha and a trade convention that opened the Ottoman markets to British products at the expense of Ottoman manufacturers in $1838,{ }^{14}$ the increasing contacts between the British and the Ottoman governments played a major role in the Ottoman state's reform campaign. Culminating in the military alliance during the Crimean War (1853-1856), ${ }^{15}$ these relations provided the Ottoman government with diplomaticmilitary protection particularly against Russia, and increasingly facilitated and encouraged the transfer of British resources for Ottoman economic transformation, particularly in the form of credits, direct investments, technology, and labor. Indeed, throughout the two decades following the Crimean War, Britain remained not only as the most important trade partner, but also had the largest share of foreign 
loans and direct investments in the Empire, the latter including the first railway lines laid out by British companies in Western Anatolia and the Balkans. ${ }^{16}$ This context played a major role in the migration of British subjects who travelled mostly with their families in this period, with the prospect of continuous employment not only in government works as the following pages will demonstrate, but also most likely in the long run, in the increasing number of British enterprises in the Empire.

James Herdman was among the earliest groups of British workers who were hired by the Ottoman state to launch an industrialization campaign in the 1830s. In this context, steam-driven machinery was ordered to European manufacturers to establish new factories or to transform production in the existing facilities, including the Imperial Arsenal and the Imperial Armory in Istanbul. ${ }^{17}$ As the Empire did not have an adequate number of skilled native workers, particularly mechanics, labor transfer inevitably accompanied technology transfer. The Ottoman bureaucrats expected these workers not only to install and run the machinery, but also to train native workers so that the labor force necessary for the industrialization program be created in the long run. ${ }^{18}$

Especially in the 1840s, the number of British workers gradually increased in parallel to the establishment of a series of state-owned mechanized factories on the outskirts of Istanbul, ranging from ironworks to textile mills, which produced for the Ottoman military. ${ }^{19}$ However, this initial experience ended up an abysmal disappointment, as most of these factories failed due to financial and managerial problems. Charles MacFarlane, who visited these factories in the mid-1840s, wrote about dozens of British workers who had been brought to work in these factories but were either sent back shortly after or "condemned to a continuation of idleness," since most of the factories were not even physically completed by that time. ${ }^{20}$ Adding to this was the high cost of these factory workers, who could be convinced to come and work in the Empire by much higher wages than they earned in their own countries. ${ }^{21}$

This was one side of the coin, as foreign workers proved their ability to cause political problems for the Ottoman authorities as well. British and other European workers often applied to their consulates or embassies in Istanbul with the expectation that the latter would pressure the Ottoman officials for the solution of their problems, mostly regarding the payment of wages. Indeed, in a period marked by the state's increasing dependence on the political, financial, and military support of European powers, Ottoman bureaucrats seem to have been particularly sensitive against the possible repercussions of a labor unrest involving European workers. In a telling instance, in July 1848, during the heydays of revolutionary uprisings in Europe, state officials reported on the complaints of European workers employed in a state-owned ironworks in Istanbul, whose wages had been in arrears for three months, and discussed the possibility of radical actions by these workers in the factory, underlining their "strange manners and circumstances." ${ }^{22}$ Indeed, such concerns, in addition to financial problems, likely deprived state elites of their motivation for rapid mechanization, until Ottoman workers would be systematically trained to replace their foreign counterparts.

Until the Crimean War, the number of foreign mechanics in the factories remained in line with the sporadic character of industrial campaign in Istanbul. In 1848 , for example, there was a total of twenty-four foreign mechanics in the 
Imperial Arsenal, the bedrock of the steam-driven mechanization campaign in the Empire. ${ }^{23}$ However, the numbers were never stable, as most of the time these workers were contracted for short periods, usually one to three years, and not all of them stayed longer than that. In most cases these workers left due to low wages and the irregularity of their payments. ${ }^{24}$ As a result, in the absence of local mechanics, such exits forced the government to find and contract new workers from British dockyards and arsenals, mostly with the help of increasing official connections between the two governments during this period.

A high turnover rate was never desirable for the Ottoman authorities, however, especially when the Ottoman military was in urgent need for such mechanics in factories and on steamships. This was not unknown to the mechanics, as they immediately acted to improve their conditions particularly during the Crimean War, which gave foreign mechanics leverage to improve their wages and working conditions. In 1854, when seven foreign workers demanded an increase in their wages, the government had to accept their requests due to the lack of options during the war. Some of these workers had been recruited only about a year before, such as a Hungarian, a French, a Swedish, and a British mechanic. The other three mechanics had been employed for a longer period. James Blair, in his seventh year at the Arsenal, believed that his commitment and hard work had earned him a promotion to the rank of second-class engineer, with a pay increase. James Carlisle, who had been working for almost eight years, five of them without a contract, gave a strongly-worded notice, warning that if his pay was not advanced, a promise which had not been kept for the past four years, he would consider himself "duly at liberty." Samuel Brown, working as the chief boiler-maker of the Boiler Shop in the Arsenal for six years, although his contract had expired three years earlier, requested the increase promised at the time of his recruitment. Upon receiving their petitions, the Naval Council initially tried to convince the workers to continue with their present wages given the existing challenges of the Treasury during the war. They refused, "firmly" stating that they would leave in case their requests were not met. The Naval Council had to give in, since there were "no mechanics to replace them in Istanbul" and recruiting new workers from London would be more expensive. ${ }^{25}$

Although the high frequency of turnover continued during the post-war economic distress in the Empire, a new era for British workers started in a short while. Indeed, during the following two decades, British labor migration saw its climax before it was almost terminated. In the era of Sultan Abdulaziz (r.1861-1876), the Ottoman state launched a naval modernization campaign, marked by the construction or purchase of several steamships and ironclads, to build a large and powerful navy. By means of foreign loans, which increasingly flowed from Europe, the number of mechanized factories and workshops in the Imperial Arsenal and, to a lesser extent, in the Imperial Armory, dramatically increased, along with Ottoman and foreign workers employed in these factories.

In spite of loans from Europe, economic problems persisted in this period, so much so that the value of kaime (paper money) plunged to such levels that the government was forced to withdraw it after protests. ${ }^{26}$ Still, the sultan pressured especially the naval administration to make huge investments on machinery and steamships, for the construction of a powerful and competitive navy as quickly as 
possible. In response, the bureaucrats sought ways to cut the labor costs as far as possible. They were unable to decrease the number of workers, since as many workers as possible were needed to rapidly complete the sultan's projects. Nor were they able to cut their wages as it immediately led to increasing turnover and workers' protests. In the end, they opted to stream the available funds towards capital investments, by keeping workers' wages in arrears as long as possible. Workers in the arsenal did not remain silent against these arrears, going on strikes from time to time. The government could only appease them by paying these arrears, albeit gradually at various installments. ${ }^{27}$

British workers, whose wages were much higher than most of their local counterparts, nevertheless continued to suffer from the problem of arrears under the reign of Abdulaziz as well. ${ }^{28}$ In 1866, a letter from the Grand Vizierate to the Ministry of Marine complained of the persistent grievances made by British subjects over the delayed payments in the Imperial Arsenal. ${ }^{29}$ As a result, many workers continued to leave immediately after the end of their contracts, sometimes forcing the administration to rearrange the assignments of the remaining foreign workers since they could not be replaced by locals. ${ }^{30}$

Still, these exits were less of a threat to the pace of production compared to earlier periods, when there were not a sufficient number of skilled workers among the locals, and when hiring new workers was more costly, a situation that gave an edge to workers' demands. By the late 1860s, however, such turnovers, at least in the case of mechanics, did not seem to concern or threaten the Ottoman authorities anymore. One reason for this was the increased availability of local mechanics, who were trained by their British masters mostly as part of military-vocational programs during this period. Indeed, from the late 1860s onward, both in the Arsenal and the Armory, Ottoman mechanics graduating from these programs started to replace their foreign counterparts. ${ }^{31}$

Another possible reason was the increasing availability of cheap labor from Britain in this decade. The financial panic of 1866 in Britain hit particularly the iron industries, including iron-shipbuilding. ${ }^{32}$ The crisis led to a growing interest among skilled industrial workers, who faced severe unemployment and a fall in wages, in possibilities of employment abroad, with the British government investigating the potential options for such workers. ${ }^{33}$ Lower wages and rising unemployment in British shipbuilding industries overlapped with the Ottoman government's demand for skilled labor in this period, especially for the construction of the first ironclad in the Arsenal, facilitating the hiring of skilled workers for this effort. ${ }^{34}$ In fact, Ottoman authorities, now having more access to and familiarity with the British labor markets, seemed to be more successful in finding new workers in Britain, at times with no need for contracts. ${ }^{35}$

Still, even in this period, British workers were able to successfully exploit the state's dependency on their skill. This was the case in shipbuilding. The introduction of ironclads in the early 1860s, an outcome of naval competition between Britain and France, increased the pressures on the Ottoman state to modernize its navy, particularly against Russia. Coupled with the sultan's insistence to construct an ironclad as quickly as possible, this context made the Ottoman naval bureaucrats less flexible in replacing the British with Ottoman workers, since the vocational programs in the Arsenal had only recently been adjusted to train iron shipbuilders. Therefore, as 
the British shipbuilding industry recovered from the crisis in the early 1870 s, and job prospects and average wages for these workers dramatically improved, this had an immediate impact on relations between these workers and the Ottoman government. In 1872, forty-nine British workers, who had been hired two years earlier for the construction of the ironclad, attempted to leave, referring to their low wages in the Ottoman Empire and the increasing job prospects in their own country. The government, although determined not to increase the wages of such temporary workers who were hired specifically for the ironclad construction, relented and increased their wages, in order not to undermine the construction process in the Arsenal. ${ }^{36}$

\section{The Making of a Working-Class Colony in the City}

The increasing pace of production throughout the 1860 s, which likely gave a sense of job security, and the relatively high purchasing power of their wages in the Ottoman Empire, coupled with the negative prospects in Britain, prompted many of these British workers to bring their families to settle in Istanbul. In the Imperial Arsenal, aside from temporary workers who were largely hired for ironclad construction, at least 128 workers were listed as "regular workers" in 1870, which confirms a correspondent's statement that British workers here relied on "continuous employment," although their wages were in arrears for as long as six months. ${ }^{37}$ Most of these workers received between 13 and 15 pounds a month, although there were a few who earned as much as 35 and as little as 3 to 4 pounds. ${ }^{38}$ As to their purchasing power, the same correspondent stated that clothing was "not unreasonable" and house rents were "seldom under 25 pounds per annum for a superior artisan in Constantinople."39

Throughout the 1860s, as their number in the Arsenal and the Armory increased, British workers settled down in what many accounts now refer to as a "colony." In fact, despite the above-mentioned consular reports underlining the negative prospects for immigrants from Britain, journalistic accounts sounded more positive in this regard. A correspondent in 1870, for example, suggested that a British subject would not feel alone in Istanbul, because the city had several English-controlled institutions, from churches and newspapers to a hospital and the English-controlled Ottoman Bank: "With the exception, perhaps, of his bread, meat, and vegetables, a patriotic Briton may make all his purchases of his fellow-countrymen, who he will find represented in every trade and profession." ${ }^{\prime 0}$

Most of the mechanics seem to have settled in Hasköy, an old Jewish village near the Imperial Arsenal, where by 1873, there were 139 British families, consisting of around 700 people. ${ }^{41}$ These "British Hasskenites," in the words of a Times correspondent, "have in their social life created for themselves a little world of their own, the type of their fatherland." 42 Together with their British counterparts in state factories, they established the Istanbul branch of the Mechanics' Institute in $1859 .{ }^{43}$ The Institute had 168 members by 1873 , who had erected a stone building in the neighborhood, by collective subscription, which provided the community with a large lecture-hall and other facilities: "The lectures are weekly and well-sustained, the reading room is supplied with the leading papers and periodicals, the library consists of more than 800 volumes, the billiard room is furnished with two good tables, and the museum-capable of extension-contains some valuable models of modern naval 
architecture and machinery." 44 The lecture hall was also used as a school for around 140 children, and according to another report in 1876, there was also a school for orphans "dependent on voluntary contributions." 45

Aside from the Institute, the community, most of whom were Scottish, had also a club, a masonic hall, and cooperative stores, as well as a Scottish minister and a Free Kirk preacher, "a sort of missionary to the Jews." 46 Many of them bought houses, and some of them built their own. ${ }^{47}$ They had a cricket team, called "Haskeui Amateurs' Sixteen," whose matches against other British teams in the city attracted non-British spectators as well, "including many Jews and Turkish women." 48 Some of them were likely active in other organizations, including the British Literary and Mechanics' Association, ${ }^{49}$ as well as fraternities such as the Society of Oddfellows and Foresters Society. ${ }^{50}$ In addition to assisting "each other in case of death and poverty amongst their comrades," they also supported other distressed British subjects in the Empire, mostly Maltese laborers, through the British Relief Society. ${ }^{51}$

As their numbers increased, they became more active in transforming the neighborhood, sometimes in a contentious way, as happened during the establishment of the "Mechanics' Club House." It was converted from a house in Hasköy to serve refreshments (including alcohol) for "respectable bachelors" who opted to have their meals in "more comfort and decency than is afforded by the eating shops of the village." The police, with the support of local shops, initially refused to give a license, under the pretext of its proximity to a mosque. The problem was resolved only after the intervention of British diplomats and a written assertion of the club owner that he would only serve the British community. ${ }^{52}$

Transforming the landscape of the neighborhood became a more acute problem after the cholera epidemic of 1871-1872, when many British, "chiefly the wives and children of engineers" of the Arsenal, passed away. ${ }^{53}$ The community and British officials held the government's enforcement of a cordon upon the neighborhood, as well as the unsanitary conditions there-particularly slaughterhouses and open sewersresponsible of these deaths. As a result of pressures from the community and British diplomats, the government had to launch initiatives to cover sewers, construct a carriage road, demolish slaughterhouses, and bring water to the neighborhood. ${ }^{54}$

These actions made British workers an important actor of the urban modernization process in a period marked by spatial and cultural transformation in Istanbul, precipitated by the urban reforms of the Tanzimat bureaucrats. ${ }^{55}$ In fact, this engagement led the British consul in the early 1870s to conclude that it was not easy for British workers to quit their jobs because of dissatisfaction with the arrears or low wages, since they "would have to make great sacrifices if they suddenly withdrew from a place which they have looked upon more or less as a permanent home."56 It was for this reason that they became more vocal about the unpaid wages and dismissals, as such problems became more striking than ever, not only for the workers but also for their entire families, who settled with them.

\section{Relations and Struggles on the Shop Floor}

In the early 1870s, the excessive burden of international debt made the payment of loans increasingly difficult, and the financial credibility of the Ottoman government 
in the European markets was in dramatic decline, leading to "rumors of bankruptcy in the European markets. ${ }^{57}$ Increasing deficits in the budget did not, however, curtail the sultan's push to continue with military expenditures, especially when tensions with Russia escalated again, leading to the Ottoman-Russian War of 1877-1878. As a result, the navy continued to buy vessels, as well as tools and machines for the existing vessels and factories, attracting the protest of Ottoman bureaucrats and their British counterparts. ${ }^{58}$

An important reason for the British diplomats to protest such expenditures as "extravagance" was the fact that they were made in a context when the government could not pay its workers regularly, including its British workers. Even before this period, arrears in payments, as we saw, were characteristic of the conditions of both British and Ottoman workers. However, as the economic crisis started to escalate, these arrears became more and more troubling, leading the workers to voice their discontent more frequently and loudly, at times with political consequences. In 1873 , Ottoman workers in the Arsenal whose wages were thirteen months in arrears, collectively stopped the sultan after a Friday prayer to present their petition about their discontent over wages and their treatment by Namik Pasha, the Minister of Marine. The sultan immediately removed him from office. ${ }^{59}$

In this context, the British workers in the Arsenal, whose wages remained unpaid as well, and who opted not to leave their jobs as many of them were now settled on a more permanent basis, also demonstrated their grievance in a number of ways. They had three options, as they told the British Consul-General in Istanbul when they visited him about their wages in $1876 .^{60}$ Their first option was to apply to the Arsenal administration to pay their wages. When they did so, they said, the pashas always made promises, only to break them later on. ${ }^{61}$ In effect, this was characteristic of the administration's response to the workers, as examples from earlier years show as well. In 1868, for example, when Thomas Hampton, an armor plate-roller, applied to the administration for payment of his wages, he was told "to wait a few days, to wait one month, and to wait generally." ${ }^{2}$

This, however, was not easy for these workers, as "waiting in a strange and expensive country means starvation and debt," since they and their families were almost exclusively dependent on their wages for their livelihoods. ${ }^{63}$ Although their wages were higher than those of local workers, their situation could become far worse than the latter when they were not paid regularly. As the Consul-General explained in his report, Ottoman workers could get rations, in the form of food items (including bread), which were denied to the foreigners, due to the latter's high wages. In addition, the British workers belonged to a very small community, unlike their local counterparts whose religious or geographical networks could obtain them "in a wonderful way" credits for their basic needs during the unpaid months. ${ }^{64}$ In other words, the lack of such networks made the British utterly vulnerable to the irregularities of payments, according to the Consul-General, as these wages were their only source of livelihood.

Therefore, it was not unexpected that just like local workers, British workers also went on strikes from time to time, perhaps as a last resort. A newspaper from August 1871, which informs us of "another strike" of British mechanics in the Arsenal, reports that the previous year, in the summer of 1870, the Ottoman authorities 
and the British workers made a deal, apparently following a strike at the time. Accordingly, in case payments remained in arrear for more than a month, workers would be "permitted" to go on strike, "strange as it may sound to factory owners in England." ${ }^{\prime \prime 5}$ This obviously reflects the Arsenal administration's concern for the continuity of production in the Arsenal, especially when the (first) ironclad, one of the sultan's dream projects, was under construction. But it also seems to point out the confidence on the part of the authorities that the British workers would not be eager to go on strike whenever they were not paid. Indeed, the newspaper also implies that this option was not used often, attributing it to workers' inability to find "volunteers" who would act as their spokesmen against the Ministry: "It is well known that in England those who make themselves conspicuous in strikes become marked men."66

In fact, according to the Consul-General's report in 1876, workers' dependence on their jobs and on their wages made them reluctant to going on strike. As industrial establishments in Istanbul were largely limited to the state factories, they had nowhere else to go when they were dismissed from the state factories due to disciplinary problems. Adding on to that was the fact that their negotiating power was increasingly weaker in the mid-1870s: Those native workers and conscripts, who were trained by the British, were now competent enough with far lower wages than their masters, encouraging the Ottoman elites to replace the latter with the former at the first opportunity. Therefore, now that many British were settled migrants in Istanbul, and leaving without a better prospect in Britain or elsewhere was their last choice; their primary interest lay in maintaining their good relations with the state authorities to keep their jobs. In fact, they wanted to avoid a "general strike" as much as possible, since it "might distort the harmony and good feeling which they desire to maintain with the government they serve."

The remaining option was to "seek the amicable intervention of the British authority with the Porte." ${ }^{68}$ As discussed above, this option was frequently used by the British workers in the earlier decades and proved to be a viable option to help these workers receive payment, since the Ottoman government was concerned with maintaining its political and economic ties with the British, as well as maintaining its financial credibility in the eyes of the Europeans. In the 1870s, a larger number of British workers in the Arsenal and other state establishments continued to keep the British authorities in Istanbul busy with their complaints, in most cases due to the irregular payment of wages. ${ }^{69}$

Such interventions at times proved to be critical enough to impact the naval projects of the Ottoman government, as it had to withdraw from some projects to be able to pay its workers. For example, in 1874, when the British Consul-General in Istanbul learned of the Ottoman government's negotiations to purchase ships from a British company, he complained: ". . . how outrageous it was for the Turkish admiralty to be spending 19,000 pounds . . whilst they were meanly pleading day after day that they had no money to pay the arrears of wages of some unfortunate British engineers." ${ }^{70}$ Upon the intervention of the British ambassador to Istanbul, the deal was cancelled, in spite of the protests of the British businessmen who were involved in it, so that the wages of mechanics working in the Aziziye Company (the state's steamship company), whose wages were in arrears for a while, could be paid. ${ }^{71}$

Struggles between the British workers and the Ottoman officials, and thus British diplomatic involvement in these relations, extended beyond the problem of unpaid 
wages, and workers' insistence to hold on to what they saw as their rights or entitlements led to serious confrontations that cost them their jobs in the early 1870s. One of these cases concerned the British mechanics in the Imperial Armory. John Mackenzie, the manager of the Gun Rolling Mill in the Armory, devised a plan to train soldiers and apprentices in the factory, which aimed for the replacement of foreign workers with "native" labor. According to the scheme, British foremen would be awarded with a range of premiums, apart from their salaries, for each native they trained, and the amount of these entitlements would increase in parallel to each trainee's degree of proficiency. According to Mackenzie, similar schemes proved to be successful in Britain and other countries. The administration approved the plan and put him in charge of implementing it. In a few years, British foremen trained several native workers, who already started to replace the foreigners. However, the promised premiums were denied to the British when a new administrator to the Tophane came in, which prompted Mackenzie, and more than a dozen of his fellow mechanics who took part in the system, to ask for the help of the British Consulate and the Embassy, who could do no more than convincing the Grand Vizier to "recommend" the Armory administration for the settlement of their claims. By this time, however, Mackenzie had already been discharged from the factory. ${ }^{72}$

Around the same period, confrontations took place regarding the working days and hours in these factories as well. By the early 1870s, since there was not a universal law or regulation that fixed the working hours and weekly holidays, even state establishments had different practices in the Ottoman Empire. ${ }^{73}$ This paved the way for potential conflicts between the Ottoman officials and British workers, since their contracts, in most cases, did not specify working hours and days. Consular documents suggest that British workers and authorities might have taken it for granted that temporal practices in Britain were to be universally applied wherever British workers were employed. When the Ottoman authorities, for instance, repeatedly pressured the British to work on Sunday, and use Friday as the day of rest, this led to the so-called "Sunday Question," since British workers refused to work on Sundays. British diplomats who were involved in the conflict argued that although the contracts did not specify the day of rest, "contracts made in England with Englishmen should be held to mean that Sunday is weekly day of rest."74

Another example concerned the British mechanics who were forced to work nine and a half hours a day in the Armory. Unlike their counterparts in the Arsenal who worked for ten hours in the summer, they normally worked at most nine hours a day, sometimes shorter, and even received overtime when they worked more than nine hours. However, in 1872, the Armory administration attempted to increase and fix working hours to nine and a half hours per day. The workers again refused to comply with this demand, arguing that this was an "innovation," and complained to the British Consulate. The Consul-General, in his dispatch to the British ambassador in Istanbul asking him to step in, justified workers' refusal in reference to the recent arrangement in England for the adoption of nine-hour workdays, and that "certainly 9 hours in Turkey is more exhausting than in England." In both cases, British intervention succeeded to revert the Ottoman attempts regarding working hours and days, although this success likely convinced the Ottoman authorities to speed up with their plan to replace the British with natives, as we will discuss below. ${ }^{75}$ 
It was probably the limited character of these confrontations with the British, as well as the knowledge that their dismissals would open new positions for native workers, that the latter were literally absent in these confrontations. Even in the case of unpaid wages, a problem common to all workers, British workers seem to act as a distinct group, as evident in the case of a general strike exclusively by British mechanics working in state factories in Istanbul, due to the two-month delay in payments. ${ }^{76}$ Unfortunately, the documents at hand give little information about the relations between the natives and the British. This may suggest that both on the shop floor and outside, contacts remained limited between these two groups. Most obviously, language was a huge barrier for such contacts, and although some of them, especially those working in the Arsenal, lived in Istanbul long enough to learn some Turkish, they probably did not need to do so in order to communicate with naval officers, most of whom learned English in the Ottoman Naval School and most likely served as their translators. Still, since their contracts stipulated that they were supposed to train local workers, they had to remain in contact at least with boys who were assigned to them as apprentices. Apart from them, there were also older local workers who apprenticed with them, mostly to master in the production and maintenance of machinery. In some registers, these latter workers were referred to as "associate workers" (refakat amelesi), who numbered sixty-one by $1875 .^{77}$

It would thus not be surprising to see that their relations with the rest of the labor force were largely limited to these apprentices, in addition to officers. In this regard, there are at least a couple of cases that may point to the existence of closer relations between these workers, to the extent that they may have formed a separate faction at least on certain occasions within the workplace. In 1868, for example, when many local workers were complaining of low and irregular wages, thirteen local workers who accompanied the British workers received a raise, after their British foreman petitioned for an increase in their wages due to their hard work. ${ }^{78}$

A more illustrative case took place in the midst of economic crisis, following the default on payment of foreign loans that the Ottoman governments had made throughout the two decades since the Crimean War. ${ }^{79}$ The bankruptcy severely hit the Ottoman economy and, in particular, state factories, as a result of which most workers either lost their jobs or could not receive their wages for long months, leading to the abovementioned strikes. In June 1876, an internal correspondence referred to the complaints of local workers about the payment of wages to the associate workers. Accordingly, when British workers were finally paid, again most likely upon the intervention of British diplomats, their associate workers also received their wages together with their masters, leading to the immediate outrage of other local workers who still had not been paid. As a result, the administration decided to pay the future wages of these associate workers together with other local workers, rather than with their masters, since doing otherwise could provoke other workers for "going on strike" and resorting to "various complaints and disturbances" in the Arsenal. ${ }^{80}$

\section{The Dissolution of the British Working-Class Colony}

As discussed, the discontent between the government and its British workers aggravated in the early 1870 s, and this was a result of a series of intentional steps taken by 
the government, to replace them with native workers especially in response to increasing financial stress in this period. It might be argued that the government always kept this intention. If one of the primary goals of employing foreign workers was running the factories with skilled labor, the other equally important goal was to train Ottoman subjects who would replace these foreigners in the long run. However, this seems not to be the course of logic on the part of British workers, as many of them invested in staying for longer periods or even permanently in Istanbul. Thus, the process of dismissal was itself a contentious process between the two sides.

In 1873, with the increasing escalation of financial troubles and the payment of wages, coupled with the belief that Ottoman workers, including conscripts, now could replace their masters, the state began to dismiss British workers. In this year alone, around fifty of the Englishmen who had worked at the Arsenal between five and fifteen years were discharged, a move that was accompanied by dismissals in the Imperial Armory as well. ${ }^{81}$ The same year, the government decreed an increase to the number of conscripts employed in the factories, in another effort to replace civilian workers (including the British) with soldiers. ${ }^{82}$ In a short while, in fact, the Porte's intention to replace all British workers with locals became clear. ${ }^{83}$

The reactions of the British community, as reflected in the protests of British diplomats and newspapers, not only demonstrate workers' discontent over these dismissals but also offer further evidence of how they expected to remain a permanent part of the workforce. Already by November 1873, the British ambassador was working hard to convince the government of stepping back from the schemes to discharge British workers, going as far as seeking an audience with the sultan for this goal. ${ }^{84}$ As these dismissals were also covered by the English press in Istanbul as well as in Britain, the government had to defend these dismissals on the ground that their contracts were over or they were not needed anymore in the navy, and that they were all paid in full. ${ }^{85}$ In effect, according to a consular dispatch in March 1874, which lamented the departure of twenty-seven engineers together with their families from Istanbul, some of the workers had left their service voluntarily, without waiting their "turn" to be dismissed. Considering this course a "suicidal folly" on the part of the government, the dispatch ended with a note of disapproval of the scheme to replace these workers with natives, warning that it would be too late if the service of these skilled British mechanics would be needed ever again, as had happened during the Crimean War in $1854 .^{86}$

British workers were most likely aware of the fact that their tenure in the Ottoman factories was coming to an end, since industry had come to a halt after the Ottoman bankruptcy in $1875 .^{87}$ Nevertheless, unlike hundreds of local workers, many of them were able to keep their jobs during the crisis, although they continued to be not paid for five or six months in a city where inflation was rampant, basic necessities were absent, and circumstances were calling for a "revolution." 88 This was most likely due to the temporary necessity of their service in the military factories and on the naval vessels upon the start of the Ottoman-Russian War of 1877-1878. By the end of the war in 1878, however, most of them would be discharged as well. ${ }^{89}$

In 1878, the British Consul-General was expecting a high number of applications to the British Relief Fund from discharged workers and their families who were unable to afford traveling back home. ${ }^{90}$ This expectation was not without grounds. 
Since most of these workers settled on a permanent basis, they had made investments with the expectation that they would continue to work, even after their contracts terminated. As we have seen, many of them bought or constructed houses for their families or invested in local societies. However, the crisis of the mid-to-late 1870s left many of these families in distress, leading them to sell their houses at far lower than their market value and to give up "their shares in social establishments." Although their original contracts included the reimbursement of their travel back home, many of them apparently could not claim it, since they continued to work without contracts afterwards. Even when they did claim such a reimbursement, it was not enough to cover all of their family members.

An illustrative case in this regard, which came to the attention of the British Consulate in 1878, also shows how the British community in Istanbul depended for their survival on their jobs in the state factories. Sarah Ellis, a seventythree-year-old woman, came to Istanbul with her husband George, who worked in the Imperial Arsenal and in the Mint. Upon his death in 1868, she continued to live in Istanbul, living for two years off the money he had left her. When her funds were exhausted, Sarah moved to the home of her daughter, whose husband, a Mr. Till, also worked in the Arsenal, until he was dismissed in September 1877. Till left Istanbul with his wife and five children shortly after, but in such a state of financial distress that he was unable to afford Sarah's travel costs. Before he left, he paid off his debts from loans he had made to sustain his family during long periods when he was not paid by the Arsenal. Sarah then moved to live with her other daughter in Istanbul, whose husband was a shipbuilder, and their three children. However, they also were in a state of distress and could not afford to maintain her within the family. In the end, the Consulate offered her the funds to travel to Liverpool, where she could live with another one of her daughters. During the trip, she would be accompanied by a Mr. Thompson, an Arsenal worker returning to England, and who "offered to take care of" her until they landed in Liverpool. ${ }^{92}$

Already by 1876, the Times correspondent "could not but regret that what had promised to become a flourishing and permanent settlement should be so likely soon to vanish from the land, leaving no trace. . ."93 Indeed, one did not have to wait long to see what he had predicted. By the end of the nineteenth century, in parallel to the increasing inactivity in production and in technology transfer following the financial crisis and the heavy defeat in the Ottoman-Russian War, the golden years of Ottoman industrial transformation were now over. In 1905, another correspondent mentioned the existence of only "one or two Englishmen and a few Germans" in the Imperial Arsenal, mourning the bygone era of British workers in what once was the jewel of Ottoman industrial modernization. ${ }^{94}$

\section{Conclusion}

The global context of industrialization and the development of political and economic connections between the Ottoman and the British states in the mid-nineteenth century are centrally significant to understand the history of industrial transformation in the Empire. The Ottoman state's efforts to remain competitive against the increasing threats to its existence pushed it to modernize its economy by adapting to the new 
technologies of production, which meant an initial dependency on the transfer of technology and skilled labor. The increasing connections with Britain beginning with the early 1840s allowed the Ottomans to partially transcend the financial constraints that limited the industrialization efforts in the earlier decades, especially by means of foreign loans after the Crimean War. This technological transformation, initially a response to defensive pressures as well as to political and economic reform efforts, possessed capitalistic attributes as well. On the one hand, industrial investments had a conscious goal of reducing labor costs through mechanization. On the other, cutting labor costs, through attempts such as replacing foreigners with local workers or withholding wages for long periods of time, made financially possible the rapid drive for such investments especially after the Crimean War. In other words, the expansion of capital was both the reason and the goal behind keeping labor costs low in this period.

British industrial workers in Ottoman state factories in Istanbul figured in the development of capitalist class relations within this context. Increasing connections with Britain led to a growing number of British workers migrating to work in government establishments, first and foremost, in the Imperial Arsenal. As both mechanization and production increased, more and more British workers started to bring their families, and settle down in Istanbul. As they did so, they considered themselves not only permanent workers, but also permanent inhabitants of Istanbul, by taking an active role in the modernization of the city. In this way, their expectations and experiences changed dramatically. They were able to develop various forms of solidarity both at the workplace and outside of it, which helped them to wage contentious -and sometimes successful-struggles against the Ottoman administrators not only over work-related problems but also over the transformation of their own neighborhoods, asserting themselves as a collective actor both in the workplace and in the city. That they saw themselves as residents, rather than temporary workers, also transformed their actions against the government for their discontent. Exiting became less of an option, and striking was risky since they could not tolerate dismissals, which pushed them to seek alternative ways, the most favorable of which was the intervention of British diplomats. These active struggles by British workers, in addition to the high cost of British labor, pushed the Ottoman government to play its own cards against these workers by capitalizing on workers' increasing dependence on their jobs in state establishments to reside in the city.

These struggles necessarily lead us to consider their role in the history of the formation of the working class in the Ottoman Empire. The findings of this research may not necessarily demonstrate that these workers developed strong class-based solidarities with their Ottoman fellows in this period. Their minimum contacts with the latter and their frequent recourse to British diplomatic intervention against the Ottoman government only confirm the fact that they distinguished, or had to distinguish, themselves from the rest of the working-class population around them. Although their willingness to stay permanently complicates this picture, one could only speculate on whether they might have developed such relations once they were allowed to stay much longer. Nevertheless, the struggles of British workers and their local civilian counterparts revealed the capitalist motives of the "reformist" bureaucrats and pushed the latter to seek cheaper and more obedient alternatives to 
them (in the body of conscripts and apprentices) for their modernization program in the rest of the nineteenth century. In this way, their struggles significantly characterized the subsequent courses of working-class formation in the Ottoman Empire. ${ }^{95}$ Thus, regardless of how they considered themselves, I believe it is impossible to write the history of working classes in the Ottoman Empire, or in any other historical or contemporary setting, by excluding these and other foreign workers merely on the basis of their national identity and their numbers. Analyzing their experiences within a larger context in the nineteenth century allows us to see how the experiences of these immigrant, or "foreign," workers could be decisive not only in the development of capitalist class relations in the Ottoman Empire but also in the making of historical processes, such as industrialization and urban transformation, that marked nineteenth-century modernity.

\section{Notes}

1. This article is partially based on my dissertation, "The Arsenal of Ottoman Modernity: Workers, Industry, and the State in Late Ottoman Istanbul" (Northeastern University, Boston, 2018). Among others, I am particularly grateful to Ilham Khuri-Makdisi, Laura L. Frader, Bengü Kurtege-Sefer, and the anonymous reviewers of ILWCH for their detailed comments and suggestions on the earlier drafts.

2. Presidential Ottoman Archives, Istanbul (hereafter BOA).İ.DH.582/40510-1, 8 February 1868. On the technological transformation of navies and naval industries in the nineteenth century, see Robert Gardiner, ed., Steam, Steel \& Shellfire: The Steam Warship 1815-1905 (London, 1992) and Lawrence Sondhaus, Naval Warfare, 1815-1914 (London and New York, 2012). For the Ottoman efforts to adopt these changes, see Levent Düzcü, Yelkenliden Buharlyya Geçişte Osmanl Denizciliği (Ottoman Maritime Transition from Sail to Steam) (1825-1855) (İstanbul, 2016).

3. For an analysis of the global history of these transformations, see C. A. Bayly, The Birth of the Modern World, 1780-1914: Global Connections and Comparisons (Oxford, 2004).

4. For an overview of Ottoman reforms and transformations in the nineteenth century, see Donald Quataert, "The Age of Reforms, 1812-1914" An Economic and Social History of the Ottoman Empire, 1300-1914, vol.2 H. Inalckk and D. Quataert, eds., (Cambridge, 1997), 759-943.

5. See Şevket Pamuk, The Ottoman Empire and European Capitalism, 1820-1913: Trade, Investment and Production (Cambridge, 1987) and Reșat Kasaba, The Ottoman Empire and the World Economy: The Nineteenth Century (Albany, 1988).

6. Throughout this essay, when referring to modernity and modernization processes in the nineteenthcentury Ottoman Empire, I will follow Berman in understanding modernity as the experience of profound historical transformations in this period, characterized by "a maelstrom of perpetual disintegration and renewal, of struggle and contradiction, of ambiguity and anguish," and modernization as the social, economic, and political processes which "[brought] this maelstrom into being, and keep it in a state of perpetual becoming." Marshall Berman, All That Is Solid Melts Into Air: The Experience of Modernity (New York, 1988), 15-16.

7. For a critical review of this literature, see Athanasios (Sakis) Gekas, "Class and Cosmopolitanism: The Historiographical Fortunes of Merchants in Eastern Mediterranean Ports," Mediterranean Historical Review 24, no. 2 (1 December 2009): 95-114.

8. Malte Fuhrmann, "I Would Rather Be in the Orient': European Lower Class Immigrants into the Ottoman Lands," in The City in the Ottoman Empire: Migration and the Making of Urban Modernity, Ulrike Freitag et al., eds., (London and New York, 2010); "North to South Migration in the Imperial Era: Workers and Vagabonds between Vienna and Constantinople," in Urban Governance Under the Ottomans, Ulrike Freitag and Nora Lafi, eds., (London and New York, 2014), 199-224; and "Down and out on the Quays of Izmir: 'European' Musicians, Innkeepers, and Prostitutes in the Ottoman Port-Cities," Mediterranean Historical Review 24, no. 2 (2009): 169-85; Julia Clancy-Smith, "'Making It' in Pre-Colonial Tunis: Migration, Work, and Poverty in a Mediterranean Port-City, c. 1815-1870," in Subalterns and Social Protest: History from Below in the Middle East and North Africa, Stephanie 
Cronin, ed. (London and New York, 2012), 227-250; Anthony Gorman, "Foreign Workers in Egypt 18821914: Subaltern or Labour Elite?" ibid., 251-274; Ilham Khuri-Makdisi, The Eastern Mediterranean and the Making of Global Radicalism, 1860-1914 (Berkeley, CA, 2010).

9. For a global perspective to the networks and patterns of mass migrations in this period, see Adam McKeown, "Global Migration, 1846-1940," Journal of World History, 2004: 155-189. Especially in the last two decades, labor historians have paid much closer attention to the movement of people, capital, and commodities across political boundaries in their analyses of working-class experiences. See Leon Fink, ed., Workers Across the Americas: The Transnational Turn in Labor History (New York, 2011); Michael P. Hanagan, "An Agenda for Transnational Labor History," International Review of Social History 49, no. 3 (2004): 455-474; Marcel van der Linden, "The Promise and Challenges of Global Labor History," International Labor and Working-Class History 82 (2012): 57-76.

10. Fabrice Bensimon, "British Workers in France, 1815-1848," Past \& Present 213, no. 1 (2011): 148. For large-scale waves of British emigration in this period, see Charlotte Erickson, Leaving England: Essays on British Emigration in the Nineteenth Century (Ithaca NY, 2019).

11. On European engineers and mechanics employed by the Ottoman state, see Darina Martykánová and Meltem Kocaman, "A Land of Opportunities: Foreign Engineers in the Ottoman Empire," in Philosophy of Globalization, Concha Roldán, Daniel Brauer, and Johannes Rohbeck. eds. (Boston, 2018), 237-252; Rahmi Deniz Özbay and Yaşar Bülbül, "Osmanlı Devleti'nde Bir Teknoloji Transferi Yöntemi Olarak Yabancı İşgücü İstihdamı" (Employment of Foreign Employees by the Ottoman Empire as a Method of Technology Transfer), Tülin Aren Armağanı, İshak Keskin et al., eds. (İstanbul, 2009), 189-218; Kadir Yıldırım, Osmanli'da İş̧̧iler (1870-1922): Çalışma Hayatı, Örgütler, Grevler (Workers in the Ottoman Empire, 1870-1922) (İstanbul, 2013), 36-48; Tuncay Zorlu, Innovation and Empire in Turkey: Sultan Selim III and the Modernisation of the Ottoman Navy (London, 2008), 77-98.

12. "Reports from H.M. Diplomatic and Consular Agents Abroad, Respecting Condition of Industrial Classes in Foreign Countries," Command Papers, 1870: 235-236.

13. The National Archives, Kew (hereafter TNA).FO.195/975, 7 July 1871.

14. Şevket Pamuk and Jeffrey G. Williamson, "Ottoman De-Industrialization, 1800-1913: Assessing the Magnitude Impact, and Response," The Economic History Review 64 (2011):161-162.

15. For a comprehensive account of this war from the Ottoman perspective, see Candan Badem, The Ottoman Crimean War (1853-1856) (Leiden, 2010).

16. Pamuk, "The Ottoman Empire and European Capitalism," 76-78; Quataert, "The Age of Reforms," 807-808.

17. On technology transfer and its role in the Ottoman efforts at industrialization, see Donald Quataert, Manufacturing and Technology Transfer in the Ottoman Empire, 1800-1914 (Istanbul, 1992).

18. Özbay and Bülbül, "Osmanlı Devleti’nde Bir Teknoloji Transferi Yöntemi Olarak Yabancı İşgücü İstihdami," 202-203.

19. For an analysis of the industrialization attempts in this period, see Edward C. Clark, "The Ottoman Industrial Revolution," International Journal of Middle East Studies 5, no.1 (1974): 65-76.

20. Charles MacFarlane, Turkey and Its Destiny: The Result of Journeys Made in 1847 and 1848 to Examine into the State of That Country, vol. 2 (London, 1850), 602.

21. Clark, "The Ottoman Industrial Revolution," 74.

22. BOA.A.\}MKT.137/38, 2 Şaban 1264 (July 4, 1848).

23. See Naval Museum Archives, Istanbul (hereafter DMA).ENV.150 for Şubat 1263 (February/March 1848).

24. See DMA.ENV.341/33,39, and 40 for exemplary records of these discharges between 1849 and 1852 .

25. BOA.İ.MVL.321/13638, 28 Rebiülevvel 1271 (19 December 1854) and BOA.A.\}MKT.MVL.MVL.70/29,

14 Rebiülahir 1271 (January 4, 1855).

26. Şevket Pamuk, A Monetary History of the Ottoman Empire (Cambridge, 2000), 211.

27. The Levant Herald, June 11, 1867, 2. The arsenal workers on strike received their payment for December 1866 on June 1867, ending their strike. The Levant Herald, June 22, 1867, 2. They received their pay for February on September, The Levant Herald, September 21, 1867, 1, and for May 1867 on July 1868, The Levant Herald, July 16, 1868, 2.

28. As a comparison of wages between local and British workers, at the Engine Factory of the Arsenal, the lowest paid British worker received 7 shillings (38.5 piasters) a day, whereas the highest paid local worker received 25 piasters. Most British workers in the Arsenal were paid above this rate, though there were at 
least some British workers who were paid remarkably lower, such as the seven workers at the Boiler Shop, who were paid between 7 and 13 piasters a day. In this factory, the average pay for local workers was around 18 piasters. See BOA.ŞD. 2/29, 25 Cemaziyülevvel 1289 (July 31, 1872).

29. BOA.A.\}MKT.MHM.354/13, 2 Zilhicce 1282 (April 18, 1866).

30. See, for example, DMA.ENV.1897/5, 27 Ramazan 1285 (January 11, 1869).

31. BOA.İ.DH.628/43659, 2 Zilhicce 1287 (February 23, 1871) and DMA.ENV.1897/10, 19 Receb 1285 (November 5, 1868).

32. For an account of the 1866 financial crisis, see Susumu Takenaga, "Marx's Exzerpthefte of the later 1860s and the Economic Crisis of 1866," Marx-Engels Jahrbuch 2015, no.1 (2016): 87-94.

33. In 1869 , the British government sent a circular to its consular and diplomatic representatives abroad to report on the condition of workers and labor markets in their respective countries, "to indicate the possible openings of which the skill and enterprise of the labouring classes may take advantage," "Reports from H.M. Diplomatic and Consular Agents Abroad," 2. These reports were supplemented the following years, in response to requests for more detailed and complete information. See "Further Reports from H.M. Diplomatic and Consular Agents Abroad, Respecting Condition of Industrial Classes and the Purchase Power of Money in Foreign Countries," Command Papers, 1871 and "Further Reports from H.M. Diplomatic and Consular Agents Abroad, Respecting Condition of Industrial Classes and the Purchase Power of Money in Foreign Countries," Command Papers, 1872.

34. Wages in shipbuilding, especially in London, fell considerably in the late 1860 s, only to dramatically increase in the next decade. See A.L. Bowley and George H. Wood, "The Statistics of Wages in the United Kingdom During the Nineteenth Century (Part XIV). Engineering and Shipbuilding. E. Averages, Index Numbers, and General Results," Journal of the Royal Historical Society 69, no. 1 (1906).

35. For examples, see DMA.ENV.1897/9 and 10 for employment records from 1868 and 1869.

36. BOA.İ.DH.648/45063, 22 Muharrem 1289 (April 1, 1872).

37. "The Industrial Classes in Turkey," Pall Mall Gazette, January 26, 1872.

38. BOA.ŞD.2/29.

39. “The Industrial Classes in Turkey,” Pall Mall Gazette, January 26, 1872.

40. "Constantinople," The Graphic, June 25, 1870.

41. "British Engineers at Constantinople," The Times, April 7, 1873.

42. Ibid.

43. MacFarlane mentions an attempt to launch a Mechanics Institute back in 1847, by the English mechanics of a factory complex, owned by the state, in Istanbul. However, in spite of an inauguration dinner, he observed that it was "an inauguration without a beginning," due to the above-mentioned problems with such factories in this period. MacFarlane, Turkey and Its Destiny: The Result of Journeys Made in 1847 and 1848 to Examine into the State of That Country, 216.

44. "British Engineers at Constantinople," The Times, April 7, 1873.

45. "English Colonies on the Bosphorus," The Times, February 22, 1876. The school for orphans was established after the cholera epidemic of 1871-1872, which hit the neighborhood hard.

46. "English Colonies on the Bosphorus," The Times, February 22, 1876. In 1847, MacFarlane also observed that there were three Free Kirk preachers settled in Constantinople, whose mission "was to convert the Jews of that city." MacFarlane, Turkey and Its Destiny: The Result of Journeys Made in 1847 and 1848 to Examine into the State of That Country, 218.

47. "English Colonies on the Bosphorus," The Times, February 22, 1876.

48. "The Ok-Meidan Cricket Match," The Levant Herald, August 8, 1871.

49. "The Literary and Mechanics' Association," The Levant Herald, January 4, 1871. The association was founded in 1871 and organized lectures and reading sessions in the English Memorial Church in Istanbul. Its honorary president was the Consul-General Sir P. Francis, who was "locally famous" for his responsiveness to "protect" the rights of British mechanics against the government. See also The Levant Herald, March $30,1872,146$.

50. The Society of Oddfellows, according to a journal article, organized an annual picnic that brought together dozens of British families in Istanbul. "Local," The Levant Herald, May 21, 1872. The "Golden Horn" court of the Foresters was established in 1870, organizing an event in the Mechanics' Institute for its third anniversary in 1872. "Foresters' Fete at Hasskeui," The Levant Herald, November 2, 1872.

51. TNA.FO.78/2245, April 10, 1872. 
52. TNA.FO.195/975, June 17, 1871.

53. TNA.FO.195/989, January 25, 1872.

54. TNA.FO.195/989, May 2, 1872 and "Local," The Levant Herald, April 22, 1872. The consular report mentions the residents' desire to buy the ground of a demolished slaughterhouse and turn it into a "place of recreation for their children." This was, most likely, the common on which the Times correspondent saw the British children playing after school in 1876. See "English Colonies on the Bosphorus," The Times, February 22, 1876.

55. For an analysis of urban reforms in the nineteenth century, see Zeynep Çelik, The Remaking of Istanbul: Portrait of an Ottoman City in the Nineteenth Century (Berkeley and Los Angeles, CA, 1993).

56. TNA.FO.195/1102, January 29, 1876.

57. Murat Birdal, The Political Economy of Ottoman Public Debt: Insolvency and European Financial Control in the Late Nineteenth Century (London; New York, 2010), 35.

58. TNA.FO.195-1022, June 29, 1873; BOA.BEO.AYN. d. 990/5, 28 Receb 1289 (October 1, 1872); DMA.ŞUB.70/243a, 12 Zilkade 1289 (January 11, 1873); and TNA.FO.195/974, November 17, 1871.

59. TNA.FO.195/1022, January 31, 1873.

60. TNA.FO.195/1102, January 29, 1876.

61. Ibid.

62. TNA.FO.195/890, May 14, 1868.

63. Ibid.

64. TNA.FO.195/1102.

65. "The Engineers' Strike at the Arsenal," The Levant Herald, August 22, 1871.

66. Ibid. (emphasis in original).

67. TNA.FO.195/1102.

68. Ibid.

69. TNA.FO.195/1145, April 17, 1877, and TNA.FO 195-1145, September 17, 1877.

70. TNA.FO.195/1044, January 13, 1874.

71. TNA.FO 195/1042, March 5, 1874.

72. TNA.FO.108/121, September 19, 1873 and TNA.FO.105/107, November 4, 1873.

73. The first Ottoman civil code in 1876 vaguely limited working hours to daylight, in line with traditional practices and acknowledging regional differences. The Ottoman state officially recognized Friday as the weekly day of rest for the first time in an 1893 regulation, which was limited only to military establishments. See Yildırım, Osmanlida İş̧̧iler (1870-1922): Çalışma Hayatı, Örgütler, Grevler, 299-306. On Ottoman bureaucratic attempts to modernize the temporal system and organization in the nineteenth century, including the temporal division between work and nonwork, see Avner Wishnitzer, Reading Clocks, Alla Turca: Time and Society in the Late Ottoman Empire (Chicago, 2015).

74. Besides the Tophane, struggles over the "Sunday Question" were particularly fierce in another stateowned military factory, the Zeytinburnu Ironworks, where workers were dismissed upon their refusal to work on Sunday. See TNA.FO.195-1024, November 6, 1873, and December 8, 1873.

75. TNA.FO.78/2245, March 8, 1872; FO 195/991, March 14, 1872; and FO.195/989, March 26, 1872.

76. Levant Herald, January 25, 1871, 962.

77. DMA.BN.225-6148, 1 Zilkade 1292 (November 29, 1875).

78. DMA.ENV.1897/2, 18 Cemaziyülevvel 1285 (September 6, 1868).

79. On Ottoman foreign loans, the bankruptcy, and its aftermath, see Edhem Eldem, "Ottoman Financial Integration with Europe: Foreign Loans, the Ottoman Bank and the Ottoman Public Debt," European Review 13, no. 3 (2005): 431-445.

80. DMA.Islahat.2/46a, 11 Cemaziyülevvel 1293, June 4, 1876.

81. "The English Artisans in Turkey," The Leeds Mercury, October 7, 1873.

82. BOA.İ.DH.667/46467, 29 Rebiülevvel 1290 (May 27, 1873).

83. "Turkey," The Morning Post, November 22, 1873.

84. TNA.FO.195/1023, November 20, 1873.

85. DMA.MKT.160-13a, 5 Zilhicce 1290 (January 24, 1874).

86. TNA.FO 195/1042, March 6, 1874.

87. "Affairs at Constantinople," Pall Mall Gazette, March 15, 1876.

88. The Western Times, May 8, 1876, 2, and "Turkey in Europe-Sailing of the Turkish Fleet Under and English Admiral," The Western Times, July 12, 1876. 


\section{Akın Sefer}

89. TNA.FO 78/2877, February 28, 1878.

90. Ibid.

91. "English Colonies on the Bosphorus," The Times, February 22, 1876.

92. TNA.FO 78/2877, January 11, 1878.

93. "English Colonies on the Bosphorus," The Times, February 22, 1876.

94. "Tershana-A Turkish Shipyard," The Engineer, December 8, 1905.

95. For an example of such connections in the context of workers' struggles in the Imperial Arsenal before and during the 1908 Revolution, see Akın Sefer. "From Class Solidarity to Revolution: The Radicalization of Arsenal Workers in the Late Ottoman Empire," International Review of Social History 58, no. 3 (2013): $395-428$. 